\title{
Transcription profiling of guanine nucleotide binding proteins during developmental regulation and pesticide response in Solenopsis invicta (Hymenoptera: Formicidae)
}

\author{
This article was published in the following Dove Press journal: \\ Open Access Insect Physiology \\ 5 October 2012 \\ Number of times this article has been viewed
}

\author{
Liming Zhao \\ Jian Chen \\ Walker A Jones \\ Biological Control of Pests Research \\ Unit, National Biological Control \\ Laboratory, Mid South Area, \\ Agricultural Research Service, United \\ States Department of Agriculture, \\ Stoneville, MS, USA
}

\begin{abstract}
Guanine nucleotide binding proteins (GNBP), glycoproteins anchored on the cytoplasmic cell membrane, are mediators for many cellular processes. Complete cDNA of the GNBP gene $\beta$-subunit (SiGNBP) was cloned and sequenced from Solenopsis invicta Buren (Hymenoptera: Formicidae) worker ants. To understand whether SiGNBP is developmentally regulated in $S$. invicta, its expression levels in different developmental stages were examined using quantitative real-time polymerase chain reaction. SiGNBP was expressed in each developmental stage, and was especially highly expressed in the late larval and early pupal stages, as well among the dealate females (queens) 10 days post nuptial flight. Quantitative real-time polymerase chain reaction also showed that mRNA transcription levels of SiGNBP in S. invicta workers were regulated during the duration of the study in response to heat shock, ultraviolet light, and boric acid treatment. These results suggest that the SiGNBP gene may play an important role in the development of $S$. invicta, and this has potential for use as a target in new insecticides for the control of fire ants.
\end{abstract}

Keywords: Solenopsis invicta, guanine nucleotide binding proteins, development, boric acid, mRNA transcription

\section{Introduction}

Transcriptional profiling is a powerful method for investigating the biological effects of chemicals and other stressors. It also offers a significant approach to identifying the relationship of gene expression to the development of the organisms. Information generated in such an approach is useful in identifying biomarkers for environmental and chemical stresses; this information can also be used in assessing new targets for drug development, such as in new insecticides for pest insect control. Guanine nucleotide binding proteins (GNBP), known as GTP-binding proteins and GTPases, are glycoproteins anchored on the cytoplasmic cell membrane, and are mediators for many cellular processes including signal transduction, protein transport, growth regulation, and polypeptide chain elongation. G- $\beta$ subunits from heterotrimeric GNBPs modulate a wide array of signaling cascades by binding directly to diverse proteins, including effectors and regulators. GNBPs have been found in a variety of animals, plants, fungi, and insects. ${ }^{1-6}$ The evolutionary aspects of GNBP-coupled receptors and their signaling pathways have revealed certain insect-specific features, ${ }^{7}$ indicating that the GNBP may be a good target for developing new specific insecticides.
Correspondence: Liming Zhao BCPRU-MSA-ARS USDA, Insect Physiology, 59 Lee Road, Stoneville, MS 38776 USA

Tel +6626863067

Fax +6626865922

Email liming.zhao@ars.usda.gov 
The red imported fire ant is a widespread pest ant with significant medical and economic importance. ${ }^{89}$ As in all organisms, the development of ants requires multigene regulation, which is affected by environmental conditions such as temperature, radiation, and challenges from pesticides and parasites. ${ }^{10-22}$ However, the role of GNBPs in Solenopsis invicta Buren development has never been examined. In this study, the complete cDNA of the guanine nucleotide-binding protein gene $\beta$-subunit ( $S i G N B P$ ) was cloned and sequenced from $S$. invicta workers, and its transcriptional expression related to the developmental stages and pesticide response was examined.

\section{Materials and methods}

\section{Fire ants}

Colonies of S. invicta were collected in Washington County, Mississippi in 2010 and 2011. All developmental stages of S. invicta, (ie, eggs, larvae, pupae, and adults - including workers, male alates, female alates, and queens) were collected at numerous time points within each stage in the laboratory. Larval stages were morphologically identified by microscopy according to the criteria of Petralia and Vinson. ${ }^{23}$ For the egg stage, $50 \mu \mathrm{g}$ of three samples were collected. For the larval stage, 50-100 larvae per sample were collected for RNA extraction. For pupae and adults, each sample contained 5-20 pupae and adults. Small workers and large workers were separated according to their sizes. An average of 20 large ants weighed $74.6 \pm 1.5 \mathrm{mg}$, while an average of 20 small ants weighed $15.6 \pm 2.19 \mathrm{mg}$. Three different colonies from Washington County, Mississippi in 2010 were used. Reproductive larvae were separated from the colony and were maintained with workers together in growth chambers in order to collect the time course samples for developmental study. Samples were frozen at $-80^{\circ} \mathrm{C}$ in a freezer, and RNA extractions were processed when the collection stage was completed. Newly dealated queens were collected in Leland, Mississippi and were used for the time course studies of queens. Three queens were collected in $1,5,10,16,21$, and 32 days, individually. The queens were provided with $10 \%$ sugar as food in a $50 \mathrm{~mL}$ glass test tube with cottons plugs. After about $8-10$ days, the queens produced their first set of eggs.

\section{RNA extraction}

Total RNAs were extracted using TRIzol reagent according to the manufacturer's instructions (Invitrogen, Life Technologies Corporation, Carlsbad, CA). Poly (A) ${ }^{+}$RNA was isolated by applying Oligotex-dT suspension (QIAGEN, Valencia, CA). mRNA samples were quantified by SmartSpec ${ }^{\mathrm{TM}}$ Plus Spectrophotometry (Bio-Rad Laboratories, Inc, Hercules, CA).

\section{GeneRacer cloning}

The GeneRacer ${ }^{\mathrm{TM}}$ kit was used to amplify the full-length gene of $5^{\prime}$ and $3^{\prime}$ cDNA ends by slightly modifying the manufacturer's instruction (Invitrogen). Polymerase chain reaction (PCR) products were cloned using the TOPO TA Cloning ${ }^{\circledR}$ kit for sequencing (Invitrogen). Transformed plasmids were inserted into One Shot ${ }^{\circledR}$ TOP10 Competent Cells (Invitrogen) and grown overnight on Luria-Bertani plates containing ampicillin and X-Gal (5-bromo-4chloro-3-indolyl- beta-D-galactopyranoside). Clones were isolated and grown overnight in LB-ampicillin broth at $37^{\circ} \mathrm{C}$, and shaken at $230 \mathrm{RPM}$ in the Thermo Scientific Analog MaxQ 4000 Shaker (Thermo Fisher Scientific Inc, Waltham, MA).

\section{Gene sequencing of GeneRacer library}

Clones of the GeneRacer library were purified with a QIAprep Miniprep (QIAGEN). The plasmid DNAs $(0.5 \mu \mathrm{g})$ were then digested using the EcoRI enzyme (2.5 U) for 1.5 hours, and were run on a $1 \%$ agarose gel to confirm the DNA insert. Selected clones were then sent to the DNA Sequencing Core at the Interdisciplinary Center for Biotechnology Research at the University of Florida (Gainesville, FL) to be sequenced and analyzed using the National Center for Biotechnology Information BLASTN program to identify sequence homologies. The sequences were submitted into the National Center for Biotechnology Information GenBank; the accession number was HM130685.

\section{cDNA synthesis for qPCR}

To ensure that genomic DNA did not contaminate the sample, the Oligotex mRNA mini Kit (QIAGEN) was used to purify total RNA. A $250 \mathrm{ng}$ aliquot of purified mRNA was reverse transcribed in a $20 \mu \mathrm{L}$ reaction volume using the Clone AMV first-Strand Synthesis Kit, while also using the Oligo (dT)20 primer for cDNA synthesis according to the manufacturer's instructions (Invitrogen). The reaction was terminated by heat inactivation at $95^{\circ} \mathrm{C}$ for $5 \mathrm{~min}$. The cDNA samples used for the quantitative real-time PCR (qPCR) analysis were taken from ants in their developmental stages undergoing boric acid treatment; controls were diluted by adding $80 \mu \mathrm{L}$ $\mathrm{ddH}_{2} \mathrm{O}(\sim 450 \pm 50 \mathrm{ng} / \mu \mathrm{L})$ and stored at $-20^{\circ} \mathrm{C}$. 
To design gene-specific primers, detailed analyses of the nucleotide sequence of genes found in the library (Genbank accession number: HM130685) were performed using the PRIMER3-Design Primer Pairs and Probes program from Biology Workbench (Department of Bioengineering, University of California, San Diego, CA). The primers for the $S$. invicta actin gene (Genbank accession number: HM130684) were also designed for internal control and comparison purposes.

\section{qPCR amplification}

The qPCR assay for the SiGNBP gene in S. invicta was performed using Platinum ${ }^{\circledR}$ SYBR $^{\circledR}$ Green qPCR SuperMix-UDG with ROX (Invitrogen) in a volume of $15 \mu \mathrm{L}$ on an Applied Biosystems 7300 Fast Real-Time PCR System (Life Technologies Corporation, Foster City, CA). The PCR mixture consisted of $1 \mu \mathrm{L}$ of diluted cDNA $(\sim 450 \pm 50 \mathrm{ng} / \mu \mathrm{L}), 0.5 \mu \mathrm{M}$ primers, and $1 \mathrm{X}$ master mix. In every qPCR run, actin was used as an internal control to normalize for variation in the amount of the cDNA template. The PCR primers for the actin gene were SiActin783-F 5'-CCTCTTCCAACCTTCCTTCC-3', SiActin-948R 5'-CTTTTGCATACGATCAGCGA-3', SiGNBP-13F 5'-TTACAGCTGAGAGGGACGCT-3', and SiGNBP-267R 5'-AAGACGCAATGTTTTGTCCC-3'. The PCR thermal cycling parameters were the same as described previously. ${ }^{22,24}$ Relative expression levels were calculated as follows. First, SiGNBP transcript levels relative to a standard (SiActin) were calculated using the following formula:

$$
\Delta \mathrm{CT}=\mathrm{CT}(\text { SiGNBP })-\mathrm{CT}(\text { SiActin })
$$

Second, an average $\Delta \mathrm{CT}$ value for each sample was calculated. Third, relative expression levels were calculated using the equation:

$$
100 \times 2^{[-\operatorname{average} \Delta \mathrm{CT}]}
$$

\section{Boric acid experiments}

Boric acid was delivered in a $10 \%$ sugar solution using feeding stations at room temperature $\left(27^{\circ} \mathrm{C}\right)$. Two concentrations were used: $0.85 \mathrm{mg} / \mathrm{mL}$ (low dose, LD) and $8.5 \mathrm{mg} / \mathrm{mL}$ (high dose, HD). To trace the RNA expression levels of differentially transcribed genes for each dose, workers (200 mg) were sampled from each of the three different colonies at 4 , 8,12 , and 14 days. Control workers were simultaneously collected from colonies that were supplied with boric acid-free sugar water. This time course study was replicated three times. mRNA was extracted and a cDNA library was created as previously described. qPCR was performed using primers designed for the genes SiGNBP and SiActin.

\section{Sequence data processing}

Multiple sequence alignments of GNBP and orthologues from other insects were performed with the Molecular Evolutionary Genetics Analysis 5.05 program (MEGA; http://www.megasoftware.net). A phylogenetic tree was constructed using the neighbor-joining method with the MEGA 5.05 program. ${ }^{25}$ The neighbor-joining method is based on the minimum-evolution criterion, and is also a bottom-up clustering method for the creation of phenetic trees. ${ }^{26}$

\section{Statistical analysis}

Comparisons of means were analyzed using the paired $t$-test, and $t$-values and $P$-values were reported when normality and equal variance tests were passed. Significant differences between the data were determined using SigmaPlot software (SigmaPlot ${ }^{\circledR} 11.2$; Systat Software, Inc, San Jose, CA).

\section{Results \\ Identification of Solenopsis invicta guanine nucleotide-binding protein subunit beta-like protein gene}

The complete cDNA sequence of the $S i G N B P$ gene of $S$. invicta was deposited in the GenBank (accession number: HM130685). SiGNBP is 951 base pairs in length, and encodes a protein of 317 amino acids with a molecular mass of $35.7 \mathrm{kDa}$. A phylogenetic tree for SiGNBP nucleic acid sequences of guanine nucleotide binding proteins from other insect orthologues was constructed using the neighborjoining method with the MEGA 5.05 program (Figure 1). The phylogenetic analysis showed that $\operatorname{SiGNBP}$ was closely related to guanine nucleotide binding proteins from Apis mellifera L. and Bombus terrestris L.

\section{SiGNBP RNA profile in different developmental stages of Solenopsis invicta}

To understand how SiGNBP is regulated during the development of $S$. invicta, qPCR was performed to examine the relative transcription levels of $S i G N B P$ in eggs, larvae, pupae, workers, male alates, female alates, and queens (Table 1A and $\mathrm{B})$. In the egg stage, the relative RNA transcription level of $S i G N B P$ ranged from $13.217 \pm 1.665$ to $58.919 \pm 0.935$. 


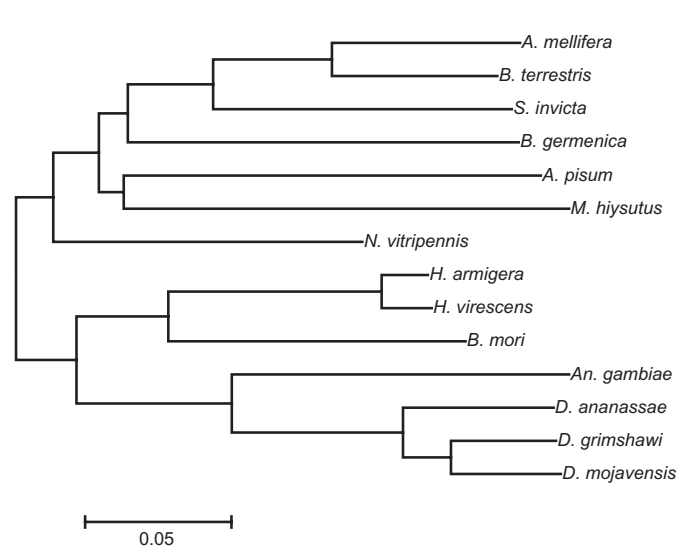

Figure I Construct/test neighbor-joining GNBP tree.

Notes: A phylogenetic tree was constructed using the neighbor-joining method for SiGNBP nucleic acid sequences of GNBPs from other insect orthologues using the MEGA 5.05 program. The scale bar indicates the number of changes inferred as having occurred along each branch. The accession numbers of reference nucleotide sequences used in this analysis are: HMI30685, XM_00339475I, XM_392962, XM_00I600I02, DQ885470.I, EF070464.I, JF4I7987.I, AF36803I.I, AF36803I.I, AY73753I.I, HM449904.I, DQ073455.I, AY588074.I, XM_001988797.I, XM_968486.2, XM_001948034.2, HQ638203.I, XM_002065I2I.I, EU2598I5.I, BX063203, and XM_002003720.I.

Abbreviations: GNBP, guanine nucleotide binding proteins; SiGNBP, guanine nucleotide binding proteins gene $\beta$-subunit.

During the early worker larval stages, SiGNBP RNA expression decreased from first instar $(37.288 \pm 1.300)$ to third instar (4.264 \pm 0.037$)$, but these levels significantly increased during the fourth instar $(111.71 \pm 1.417)$ as compared to the third instar (Table 1A, and supplementary Table S1).

For reproductive larvae, SiGNBP RNA expression increased significantly in the fourth instar as compared to all the early instars, reaching ( $35.525 \pm 0.425)$ (Table 1B and supplementary Table S1). There was a high SiGNBP RNA expression in early reproductive pupae (144.053 \pm 1.997$)$; however, expression significantly decreased in the late reproductive pupae. The SiGNBP RNA expression level was similar in the younger small workers, larger workers, and female alates (Table $1 \mathrm{~A}$ and $\mathrm{B}$ ).

In the male alates and queens, the relative $S i G N B P$ RNA levels were differentially expressed from teneral male alates $(8.249 \pm 0.395)$ to the mature male alates $(95.703 \pm 4.111)$ (Table 1B and supplementary Table S1). The relative SiGNBP RNA levels were differentially expressed in queens' postnuptial flight. About 10 days postnuptial flight, the relative SiGNBP RNA expression reached its highest expression level ( $991.56 \pm 15.46)$, which is significantly increased compared with day $1(4.855 \pm 1.842)$ and day $5(57.784 \pm 0.821)$ (Table 1B and supplementary Table S1). However, the relative $S i G N B P$ RNA expression level was significantly reduced among the queens at 16 days postnuptial flight, as compared with the queens at day 10 postnuptial flight (Table 1B and supplementary Table S1).

\section{Effects of boric acid on SiGNBP gene expression}

To determine whether the transcription of $S i G N B P$ in $S$. invicta was affected by boric acid treatment, workers were treated with different concentrations of boric acid in a $10 \%$ sugar solution. The qPCR time courses of SiGNBP expressed in workers were different between the two concentrations of the boric acid (HD and LD). In workers, relative SiGNBP expression levels increased two-fold for LD at 4 days of boric acid treatment, and then slightly increased for LD at 8-day and 12-day boric acid treatments compared with controls (Table 2A and B, Figure 2, and supplementary Table S2). After 14 days, SiGNBP expression was slightly decreased for LD boric acid when treatment compared with the control treatment of $10 \%$ sugar alone. However, boric acid HD-treated workers showed a decrease in SiGNBP RNA expression at 4, 8, 12, and 14-day exposures. Boric acid HD-treated workers showed a decrease in SiGNBP RNA expression (Figure 2, Table 2A and B, and supplementary Table S2).

\section{Discussion SiGNBP gene expression during Solenopsis invicta development}

We examined and analyzed changes in SiGNBP RNA expression in S. invicta eggs, larvae, pupae, and adults. The SiGNBP gene was expressed in varying quantities during the egg and early instar stages. Previous studies showed that different forms of GNBP-coupled sensory transduction may mediate developmental interactions during both early and late stages of Drosophila embryogenesis. ${ }^{6}$ Guanine nucleotide-binding proteins mediate signals between serotonin receptors and adenylate cyclase in Schistosoma mansoni, which indicates that the expression of this gene is developmentally mediated. ${ }^{10}$

There were significant differences in the expression of the SiGNBP gene between early (first to third instars) and late larval stages of worker ants (fourth instar). In addition, the expression of the $S i G N B P$ gene in the early pupal stage was significantly higher than that in the late pupal stages of both worker and reproductive ants. These changes may indicate that the expression of the SiGNBP gene is important for late larval and pupal development in S. invicta. The fourth instar larvae play a critical role in the survival of the colony; they digest solid foods and provide protein and other nutrients to the other members in the colony. ${ }^{15}$ An ant colony may be sensitive toward any disruption to the fourth instar larvae. ${ }^{15}$ $S i G N B P$ was highly expressed in fourth instar larvae, which may suggest that $S i G N B P$ is important to fourth instar larvae 
Table IA Expression of SiGNBP in different developmental stages of Solenopsis invicta

\begin{tabular}{|c|c|c|c|c|c|c|c|}
\hline \multirow{2}{*}{$\begin{array}{l}\text { Sample } \\
\text { stage }\end{array}$} & \multirow{2}{*}{$\begin{array}{l}\text { Sample } \\
\text { name }\end{array}$} & \multicolumn{2}{|l|}{ Mean Ct \pm SD } & \multicolumn{4}{|c|}{ Relative SiGNBP expression level } \\
\hline & & SiActin & SiGNBP & $\Delta \mathrm{Ct}-\mathrm{I}$ & $\Delta \mathrm{Ct}-2$ & $\Delta \mathrm{Ct}-3$ & $100 \times 2^{-\Delta C t} \pm S D$ \\
\hline \multirow[t]{4}{*}{ Egg } & Egg I & $21.325 \pm 0.157$ & $24.245 \pm 0.024$ & 2.738 & 3.101 & 2.920 & $13.217 \pm 1.665$ \\
\hline & Egg 2 & $16.488 \pm 0.004$ & $|7.25| \pm 0.026$ & 0.786 & 0.740 & 0.763 & $58.919 \pm 0.935$ \\
\hline & Egg 3 & $|8.19| \pm 0.086$ & $18.978 \pm 0.040$ & 0.833 & $0.74 I$ & 0.787 & $57.951 \pm 1.848$ \\
\hline & Egg 4 & $19.839 \pm 0.308$ & $21.549 \pm 0.058$ & 1.651 & 1.767 & 1.709 & $30.582 \pm 1.233$ \\
\hline \multirow[t]{4}{*}{ Larvae } & $\mathrm{LI}$ & $18.733 \pm 0.010$ & $20.157 \pm 0.041$ & 1.474 & 1.373 & 1.423 & $37.288 \pm 1.300$ \\
\hline & L2 & $18.5 \mid 8 \pm 0.002$ & $21.172 \pm 0.015$ & 2.666 & $2.64 I$ & 2.654 & $15.893 \pm 0.140$ \\
\hline & L3 & $18.040 \pm 0.029$ & $22.592 \pm 0.016$ & 4.563 & 4.540 & 4.552 & $4.264 \pm 0.037$ \\
\hline & L4 & $21.171 \pm 0.007$ & $21.012 \pm 0.017$ & -0.178 & -0.141 & -0.160 & $111.71 \pm 1.417$ \\
\hline \multirow[t]{2}{*}{ Pupae } & $\mathrm{PI}$ & $19.687 \pm 0.045$ & $20.860 \pm 0.07 \mid$ & 1.148 & 1.198 & 1.173 & $44.353 \pm 0.781$ \\
\hline & $\mathrm{P} 2$ & $17.163 \pm 0.035$ & $22.447 \pm 0.015$ & 5.333 & 5.235 & 5.284 & $2.567 \pm 0.088$ \\
\hline \multirow{6}{*}{$\begin{array}{l}\text { Small } \\
\text { workers }\end{array}$} & SW & $18.215 \pm 0.193$ & $|9.448 \pm 0.02|$ & 1.060 & 1.405 & 1.233 & $42.558 \pm 5.098$ \\
\hline & SW & $17.278 \pm 0.088$ & $18.999 \pm 0.029$ & 1.604 & 1.838 & 1.721 & $30.335 \pm 2.462$ \\
\hline & SW & $17.391 \pm 0.152$ & $19.374 \pm 0.010$ & 1.831 & 2.134 & 1.983 & $25.305 \pm 2.656$ \\
\hline & SW & $18.688 \pm 0.008$ & $22.266 \pm 0.034$ & 3.621 & 3.536 & 3.579 & $8.370 \pm 0.246$ \\
\hline & SW & $18.397 \pm 0.025$ & $22.064 \pm 0.061$ & 3.631 & 3.704 & 3.667 & $7.871 \pm 0.198$ \\
\hline & SW & $18.028 \pm 0.003$ & $21.143 \pm 0.012$ & 5.022 & 4.911 & 4.966 & $3.199 \pm 0.124$ \\
\hline \multirow{6}{*}{$\begin{array}{l}\text { Larger } \\
\text { workers }\end{array}$} & LW & $16.076 \pm 0.024$ & $17.710 \pm 0.010$ & 1.640 & 1.613 & 1.627 & $32.386 \pm 0.299$ \\
\hline & LW & $|6.672 \pm 0.06|$ & $18.878 \pm 0.024$ & 2.243 & 2.170 & 2.206 & $21.673 \pm 0.549$ \\
\hline & LW & $18.029 \pm 0.023$ & $20.991 \pm 0.002$ & 2.965 & 2.982 & 2.974 & $12.730 \pm 0.28 \mid$ \\
\hline & LW & $18.028 \pm 0.013$ & $21.143 \pm 0.012$ & 3.124 & 3.107 & 3.116 & $1 \mathrm{I} .538 \pm 0.070$ \\
\hline & LW & $17.862 \pm 0.036$ & $21.620 \pm 0.025$ & 3.748 & 3.770 & 3.759 & $7.388 \pm 0.056$ \\
\hline & LW & $18.122 \pm 0.016$ & $23.018 \pm 0.076$ & 4.803 & 4.896 & 4.988 & $3.360 \pm 0.216$ \\
\hline
\end{tabular}

Abbreviations: SiGNBP, guanine nucleotide binding proteins gene $\beta$-subunit; $\mathrm{Ct}$, cycle threshold; SD, standard deviation.

Table IB Expression of SiGNBP in different developmental stages of Solenopsis invicta

\begin{tabular}{|c|c|c|c|c|c|c|c|}
\hline \multirow{2}{*}{$\begin{array}{l}\text { Sample } \\
\text { stage }\end{array}$} & \multirow{2}{*}{$\begin{array}{l}\text { Sample } \\
\text { name }\end{array}$} & \multicolumn{2}{|l|}{ Mean $\mathbf{C t} \pm$ SD } & \multicolumn{4}{|c|}{ Relative SiGNBP expression level } \\
\hline & & SiActin & SiGNBP & $\Delta \mathrm{Ct}-\mathrm{I}$ & $\Delta \mathrm{Ct}_{\mathrm{t}-2}$ & $\Delta \mathrm{Ct}_{\mathrm{t}-3}$ & $100 \times 2^{-\Delta C t} \pm S D$ \\
\hline \multirow{4}{*}{$\begin{array}{l}\text { Reproductive } \\
\text { larvae }\end{array}$} & RLI & $16.248 \pm 0.007$ & $19.364 \pm 0.019$ & 3.129 & 3.116 & 3.103 & $11.537 \pm 0.102$ \\
\hline & RL2 & $16.235 \pm 0.004$ & $20.139 \pm 0.007$ & 3.915 & 3.894 & 3.904 & $6.678 \pm 0.050$ \\
\hline & RL3 & $15.125 \pm 0.011$ & $18.148 \pm 0.036$ & 2.998 & 3.048 & 3.023 & $12.304 \pm 0.263$ \\
\hline & RL4 & $16.083 \pm 0.022$ & $17.560 \pm 0.039$ & 1.459 & 1.493 & 1.476 & $35.525 \pm 0.425$ \\
\hline Reproductive & RPI & $19.147 \pm 0.007$ & $\mid 8.621 \pm 0.027$ & -0.507 & -0.547 & -0.527 & $144.05 \pm 1.997$ \\
\hline pupae & RP2 & $19.623 \pm 0.046$ & $21.610 \pm 0.075$ & 1.959 & 2.015 & 1.987 & $25.225 \pm 0.495$ \\
\hline \multirow[t]{3}{*}{ Female alates } & FA & $17.150 \pm 0.022$ & $18.354 \pm 0.028$ & 1.199 & 1.210 & 1.205 & $43.386 \pm 0.162$ \\
\hline & FA & $19.219 \pm 0.003$ & $21.012 \pm 0.039$ & $\mathrm{I} .738$ & $\mathrm{I} .847$ & 1.793 & $28.860 \pm 1.091$ \\
\hline & FA & $18.015 \pm 0.003$ & $21.136 \pm 0.029$ & 3.153 & 3.089 & 3.121 & $11.493 \pm 0.253$ \\
\hline \multirow[t]{6}{*}{ Male alates } & $M A I^{a}$ & $|8.7| 4 \pm 0.023$ & $22.314 \pm 0.046$ & 3.531 & 3.669 & 3.599 & $8.249 \pm 0.395$ \\
\hline & MA4 & $16.753 \pm 0.036$ & $21.648 \pm 0.113$ & 4.971 & 4.817 & 4.894 & $3.362 \pm 0.178$ \\
\hline & MA8 & $19.733 \pm 0.012$ & $22.962 \pm 0.005$ & 3.212 & 3.246 & 3.229 & $10.666 \pm 0.124$ \\
\hline & MAI2 & $18.478 \pm 0.026$ & $22.075 \pm 0.17 \mid$ & 3.452 & 3.742 & 3.597 & $8.265 \pm 0.832$ \\
\hline & MAI4 & $24.174 \pm 0.056$ & $24.237 \pm 0.118$ & 0.001 & 0.125 & 0.063 & $95.703 \pm 4.1 \mathrm{I} I$ \\
\hline & MAI8 & $21.121 \pm 0.492$ & $23.547 \pm 0.121$ & 2.205 & 2.426 & 2.630 & $18.817 \pm 2.772$ \\
\hline \multirow[t]{6}{*}{ Queens } & $\mathrm{QI}^{\mathrm{b}}$ & $18.193 \pm 0.079$ & $22.307 \pm 0.07 \mid$ & 4.105 & 4.123 & 4.114 & $5.775 \pm 0.035$ \\
\hline & Q5 & $20.659 \pm 0.005$ & $21.451 \pm 0.003$ & 0.789 & 0.793 & 0.791 & $57.784 \pm 0.821$ \\
\hline & Q10 & $26.346 \pm 0.058$ & $23.037 \pm 0.036$ & -3.332 & -3.287 & -3.310 & $991.56 \pm 15.46$ \\
\hline & Q16 & $19.137 \pm 0.040$ & $22.762 \pm 0.065$ & 3.649 & 3.601 & 3.625 & $8.106 \pm 0.136$ \\
\hline & Q2I & $21.078 \pm 0.030$ & $22.177 \pm 0.011$ & 1.080 & 1.118 & 1.099 & $46.679 \pm 0.607$ \\
\hline & Q32 & $19.205 \pm 0.038$ & $20.969 \pm 0.142$ & 1.868 & 1.660 & 1.764 & $29.445 \pm 2.123$ \\
\hline
\end{tabular}

Notes: aMale alates day post emerging from reproductive pupae; bdealate female (queens) day post nuptial flight.

Abbreviations: SiGNBP, guanine nucleotide binding proteins gene $\beta$-subunit; $C t$, cycle threshold; SD, standard deviation. 
Table 2A Expression of SiGNBP under boric acid feeding conditions in Solenopsis invicta

\begin{tabular}{|c|c|c|c|c|c|}
\hline \multirow[t]{2}{*}{ Time point } & \multicolumn{2}{|l|}{$C t \pm S D$} & \multicolumn{3}{|c|}{ Relative SiGNBP expression level } \\
\hline & SiActin & SiGNBP & $\Delta \mathrm{Ct}-\mathrm{I}$ & $\Delta \mathrm{Ct}-2$ & $\Delta \mathrm{Ct}-3$ \\
\hline Cont-4d'a & $19.023 \pm 0.121$ & $21.842 \pm 0.041$ & 2.656 & 2.981 & 2.818 \\
\hline Cont-8d ${ }^{a}$ & $18.029 \pm 0.023$ & $20.991 \pm 0.002$ & 2.965 & 2.982 & 2.974 \\
\hline Cont- $12 d^{a}$ & $18.028 \pm 0.013$ & $21.143 \pm 0.012$ & 3.124 & 3.107 & 3.116 \\
\hline Cont-14 & $17.770 \pm 0.083$ & $20.727 \pm 0.052$ & 2.988 & 2.927 & 2.957 \\
\hline$B A-4 d^{b}$ & $19.230 \pm 0.025$ & $22.114 \pm 0.011$ & 2.848 & 2.884 & 2.920 \\
\hline$B F-8 d^{b}$ & $18.156 \pm 0.044$ & $21.282 \pm 0.037$ & 3.133 & 3.120 & 3.126 \\
\hline$B F-12 d^{b}$ & $18.760 \pm 0.116$ & $22.282 \pm 0.037$ & 3.968 & 3.841 & 3.905 \\
\hline BF-14d & $19.266 \pm 0.011$ & $23.766 \pm 0.123$ & 4.365 & 4.634 & 4.499 \\
\hline
\end{tabular}

Notes: ${ }^{a}$ Nonboric acid, only $10 \%$ sugar feeding in Solenopsis invicta workers; bboric acid $(0.85 \mathrm{mg} / \mathrm{mL})$ within $10 \%$ sugar feeding in Solenopsis invicta workers.

Abbreviations: SiGNBP, guanine nucleotide binding proteins gene $\beta$-subunit; $\mathrm{Ct}$, cycle threshold.

and thus is an excellent target for developing intervening methods, such as a new insecticide.

Numerous physiological changes occur during the development of ant adults. A previous study showed that arginine kinase, a primary enzyme in cell metabolism and adenosine 5 -triphosphate-consuming processes, was differentially expressed among larvae and adults, queens and workers, and among female alates and queens. ${ }^{12}$ The results showed that the $S i G N B P$ gene is not only differentially expressed among eggs, larvae, adults, workers, female alates, and queens, but it is also differentially expressed within the larval (ie, first instar, second instar, third instar, and fourth instar), pupal (early and late pupae), as well as the worker (early and late workers) stages. The relatively low levels of SiGNBP expression in older workers and female alates suggest that the $S i G N B P$ gene may play a role in the attenuation of gene expression.

\section{SiGNBP gene responses to pesticide}

Many insecticides or repellents, including bifenthrin, chlorfenapyr, fipronil, and thiamethoxam, have been evaluated for activity against the red imported fire ant, $S$. invicta. ${ }^{28-32}$ Molecular studies of insecticide resistance, including identification of the genes involved in target site and metabolic resistance mechanisms, have advanced rapidly over the past decade..$^{32-34}$ A previous study showed that boric acid significantly decreased the survivorship of workers in the target organs. ${ }^{35}$

SiGNBP expression levels of worker $S$. invicta were upregulated at 4,8 , and 12 days, and were downregulated at 14 days after a low dose of boric acid treatment. However, SiGNBP expression levels were downregulated at 4, 8, 12, and 14 days after a high dose of boric acid treatment.

In conclusion, expression of the $S i G N B P$ gene in the life cycle of $S$. invicta was highly regulated developmentally and environmentally. SiGNBP RNA expression has, for the first time, been examined in detail for all developmental stages of $S$. invicta. The current study suggests that $S i G N B P$ plays an important role in the development of S. invicta, and it may provide useful information for designing novel strategies for fire ant control. Using RNA interference technology to knock down the $S i G N B P$ gene may provide additional targets that can be developed as new pesticides.

Table 2B Expression of SiGNBP under boric acid feeding conditions in Solenopsis invicta

\begin{tabular}{|c|c|c|c|c|c|}
\hline \multirow[t]{2}{*}{ Time point } & \multicolumn{2}{|l|}{$C t \pm S D$} & \multicolumn{3}{|c|}{ Relative SiGNBP expression level } \\
\hline & SiActin & SiGNBP & $\Delta \mathrm{Ct}-\mathrm{I}$ & $\Delta \mathrm{Ct}-2$ & $\Delta \mathrm{Ct}-3$ \\
\hline Cont-4d'a & $19.023 \pm 0.121$ & $21.842 \pm 0.041$ & 2.656 & 2.981 & 2.818 \\
\hline Cont- $8 d^{a}$ & $18.029 \pm 0.023$ & $20.991 \pm 0.002$ & 2.965 & 2.982 & 2.974 \\
\hline Cont- $12 \mathrm{~d}^{\mathrm{a}}$ & $18.028 \pm 0.013$ & $21.143 \pm 0.012$ & 3.124 & 3.107 & 3.116 \\
\hline Cont- $14^{a}$ & $17.770 \pm 0.083$ & $20.727 \pm 0.052$ & 2.988 & 2.927 & 2.957 \\
\hline$B A-4 d^{b}$ & $19.230 \pm 0.025$ & $22.114 \pm 0.011$ & 2.848 & 2.884 & 2.920 \\
\hline$B F-8 d^{b}$ & $18.156 \pm 0.044$ & $21.282 \pm 0.037$ & 3.133 & 3.120 & 3.126 \\
\hline$B F-12 d^{b}$ & $18.760 \pm 0.116$ & $22.282 \pm 0.037$ & 3.968 & 3.841 & 3.905 \\
\hline$B F-14 d^{b}$ & $19.266 \pm 0.011$ & $23.766 \pm 0.123$ & 4.365 & 4.634 & 4.499 \\
\hline
\end{tabular}

Notes: ${ }^{a}$ Nonboric acid, only $10 \%$ sugar feeding in Solenopsis invicta workers; boric acid $(0.85 \mathrm{mg} / \mathrm{mL})$ within $10 \%$ sugar feeding in Solenopsis invicta workers.

Abbreviations: SiGNBP, guanine nucleotide binding proteins gene $\beta$-subunit; $\mathrm{Ct}$, cycle threshold. 
A

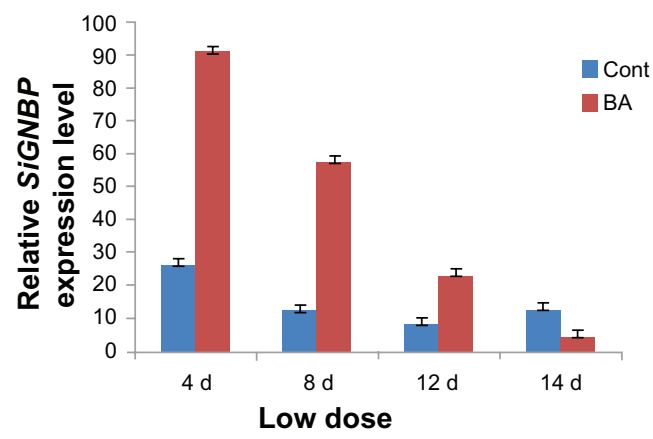

B

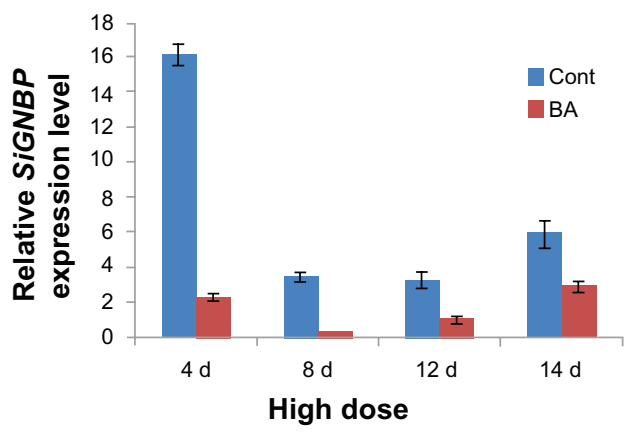

Figure 2 Boric acid treatment.

Notes: The SiGNBP transcription level in response to boric acid treatments, quantified by qPCR. S. invicta workers were exposed to low dose ( $0.85 \mathrm{mg} / \mathrm{mL})$, and high dose $(\mathrm{HD}, 8.5 \mathrm{mg} / \mathrm{mL})$ at $4,8,12$, and 14 days.

Abbreviations: Cont, control; BA, boric acid; SiGNBP, guanine nucleotide binding proteins gene $\beta$-subunit; qPCR, quantitative real-time polymerase chain reaction.

\section{Acknowledgments}

We thank Drs. Zibiao Guo (University of Mississippi Medical Center) and Cesar Solorzano Torres (USDA-ARS) for critical reviews of the manuscript. We also thank Richard Evans and Sharla Burke (USDA-ARS) for technical support.

\section{Disclosure}

The authors report no conflict of interest in this work.

\section{References}

1. Kinoshita M. The septins. Genome Biol. 2003;4(11):236.

2. Friedman EJ, Temple BR, Hicks SN, Sondek J, Jones CD, Jones AM. Prediction of protein-protein interfaces on G-protein beta subunits reveals a novel phospholipase $\mathrm{C}$ beta2 binding domain. $J$ Mol Biol. 2009;392(4):1044-1054.

3. Miura N, Atsumi S, Tabunoki H, Sato R. Expression and localization of three $\mathrm{G}$ protein alpha subunits, Go, Gq, and Gs, in adult antennae of the silkmoth (Bombyx mori). J Comp Neurol. 2005;485(2): 143-152.

4. Mosser VA, Amana IJ, Schimerlik MI. Kinetic analysis of M2 muscarinic receptor activation of Gi in Sf9 insect cell membranes. J Biol Chem. 2002;277(2):922-931.

5. Quan F, Thomas L, Forte M. Drosophila stimulatory G protein alpha subunit activates mammalian adenylyl cyclase but interacts poorly with mammalian receptors: implications for receptor-G protein interaction Proc Natl Acad Sci U S A. 1991;88(5):1898-1902.

6. Wolfgang WJ, Quan F, Thambi N, Forte M. Restricted spatial and temporal expression of G-protein alpha subunits during Drosophila embryogenesis. Development. 1991;113(2):527-538.

7. Broeck J. Insect G protein-coupled receptors and signal transduction. Arch Insect Biochem Physiol. 2001;48(1):1-12.

8. Ascunce MS, Yang CC, Oakey J, et al. Global invasion history of the fire ant Solenopsis invicta. Science. 2011;331(6020):1066-1068.

9. Vinson SB. Invasion of the red imported fire ant (Hymenoptera: Formicidae): spread, biology, and impact. American Entomologist 1997;43:23-39.

10. Iltzsch MH, Bieber D, Vijayasarathy S, et al. Cloning and characterization of a cDNA coding for the alpha-subunit of a stimulatory G protein from Schistosoma mansoni. J Biol Chem. 1992;267(20): 14504-14508.
11. Graber SG, Figler RA, Kalman-Maltese VK, Robishaw JD, Garrison JC. Expression of functional $\mathrm{G}$ protein beta gamma dimers of defined subunit composition using a baculovirus expression system. $J$ Biol Chem. 1992;267(19):13123-13126.

12. Wang H, Zhang L, Lin Q, Liu N. Arginine kinase: differentiation of gene expression and protein activity in the red imported fire ant, Solenopsis invicta. Gene. 2009;430(1-2):38-43.

13. Liu N, Zhang L. CYP4AB1, CYP4AB2, and Gp-9 gene overexpression associated with workers of the red imported fire ant, Solenopsis invicta Buren. Gene. 2004;327(1):81-87.

14. Tracy JM, Demain JG, Quinn JM, Hoffman DR, Goetz DW, Freeman TM. The natural history of exposure to the imported fire ant (Solenopsis invicta). J Allergy Clin Immunol. 1995;95(4):824-828.

15. Whitworth ST, Blum MS, Travis J. Proteolytic enzymes from larvae of the fire ant, Solenopsis invicta. Isolation and characterization of four serine endopeptidases. J Biol Chem. 1998;273(23):14430-14434.

16. Shoemaker DD, Ross KG, Keller L, Vargo EL, Werren JH. Wolbachia infections in native and introduced populations of fire ants (Solenopsis spp.). Insect Mol Biol. 2000;9(6):661-673.

17. Haisheng T, Bradleigh VS, Coates CJ. Differential gene expression between alate and dealate queens in the red imported fire ant, Solenopsis invicta Buren (Hymenoptera: Formicidae). Insect Biochem Mol Biol. 2004;34(9):937-949.

18. Valles SM, Strong CA, Dang PM, et al. A picorna-like virus from the red imported fire ant, Solenopsis invicta: initial discovery, genome sequence, and characterization. Virology. 2004;328(1):151-157.

19. Folgarait PJ, Patrock RJ, Gilbert LE. Development of Pseudacteon nocens (Diptera: Phoridae) on Solenopsis invicta and Solenopsis richteri fire ants (Hymenoptera: Formicidae). J Econ Entomol. 2006;99(2):295-307.

20. Park J, Kaufmann GF, Bowen JP, Arbiser JL, Janda KD. Solenopsin A, a venom alkaloid from the fire ant Solenopsis invicta, inhibits quorum-sensing signaling in Pseudomonas aeruginosa. J Infect Dis. 2008;198(8):1198-1201.

21. Tufts DM, Bextine B. Identification of bacterial species in the hemolymph of queen Solenopsis invicta (Hymenoptera: Formicidae). Environ Entomol. 2009;38(5):1360-1364.

22. Zhao L, Pridgeon JW, Becnel JJ, Clark GG, Linthicum KJ. Cytochrome c gene and protein expression: developmental regulation, environmental response, and pesticide sensitivity in Aedes aegypti. J Med Entomol. 2008;45(3):401-408.

23. Petralia RS, Vinson SB. Developmental morphology of larvae and eggs of the imported fire ant, Solenopsis invicta. Annals of the Entomological Society of America. 1979;72(4):472-484. 
24. Zhao L, Pridgeon JW, Becnel JJ, Clark GG, Linthicum KJ. Identification of genes differentially expressed during heat shock treatment in Aedes aegypti. J Med Entomol. 2009;46(3):490-495.

25. Tamura K, Peterson D, Peterson N, Stecher G, Nei M, Kumar S. MEGA5: molecular evolutionary genetics analysis using maximum likelihood, evolutionary distance, and maximum parsimony methods. Mol Biol Evol. 2011;28(10):2731-2739.

26. Saitou N, Nei M. The neighbor-joining method: a new method for reconstructing phylogenetic trees. Mol Biol Evol. 1987;4(4):406-425.

27. Wiltz BA, Suiter DR, Gardner WA. Activity of bifenthrin, chlorfenapyr, fipronil, and thiamethoxam against red imported fire ants (Hymenoptera: Formicidae). J Econ Entomol. 2010;103(3):754-761.

28. Chen J, Shang H, Jin X. Interspecific variation of Delta1,6-piperideines in imported fire ants. Toxicon. 2010;55(6):1181-1187.

29. Chen J. Repellency of an over-the-counter essential oil product in China against workers of red imported fire ants. J Agric Food Chem. 2009;57(2):618-622.

30. Oi DH, Oi FM. Speed of efficacy and delayed toxicity characteristics of fast-acting fire ant (Hymenoptera: Formicidae) baits. J Econ Entomol. 2006;99(5):1739-1748.
31. Appel AC, Gehret MJ, Tanley MJ. Repellency and toxicity of mint oil granules to red imported fire ants (Hymenoptera: Formicidae). J Econ Entomol. 2004;97(2):575-580.

32. Zhu F, Parthasarathy R, Bai H, et al. A brain-specific cytochrome P450 responsible for the majority of deltamethrin resistance in the QTC279 strain of Tribolium castaneum. Proc Natl Acad Sci U SA. 2010; 107(19):8557-8562.

33. Wu S, Li M, Tang PA, Felton GW, Wang JJ. Cloning and characterization of acetylcholinesterase 1 genes from insecticide-resistant field populations of Liposcelis paeta Pearman (Psocoptera: Liposcelididae). Insect Biochem Mol Biol. 2010;40(5):415-424.

34. Marcombe S, Poupardin R, Darriet F, et al. Exploring the molecular basis of insecticide resistance in the dengue vector Aedes aegypti: a case study in Martinique Island (French West Indies). BMC Genomics. 2009; 10:494.

35. Sumida S, Silva-Zacarin EC, Decio P, Malaspina O, Bueno FC, Bueno OC. Toxicological and histopathological effects of boric acid on Atta sexdens rubropilosa (Hymenoptera: Formicidae) workers. J Econ Entomol. 2010;103(3):676-690. 


\section{Supplemental material}

Table SI A Paired $t$-test data for comparison of relative SiGNBP gene transcription between developmental stages in Solenopsis invicta

\begin{tabular}{lllll}
\hline Stage and ages & N & Df & t-value & $P$-value \\
\hline LI and L2 & 3 & 2 & 93.606 & $<0.00 I^{*}$ \\
L2 and L3 & 3 & 2 & 38.995 & $<0.00 I^{*}$ \\
L3 and L4 & 3 & 2 & -55.610 & $<0.00 I^{*}$ \\
L4 and PI & 3 & 2 & 49.385 & $<0.00 I^{*}$ \\
PI and P2 & 3 & 2 & 85.455 & $<0.00 I^{*}$ \\
SW(Y) and SW(O) & 3 & 2 & 13.107 & $=0.006^{*}$ \\
LW(Y) and LW(O) & 3 & 2 & 591.843 & $<0.00 I^{*}$ \\
\hline
\end{tabular}

Note: *Statistical significance $(P<0.05)$.

Abbreviations: SiGNBP, guanine nucleotide binding proteins gene $\beta$-subunit; SW, small worker; LW, large worker.

Table S I B Paired $t$-test data for comparison of relative SiGNBP gene transcription between developmental stages in Solenopsis invicta

\begin{tabular}{lllll}
\hline Stage and ages & N & Df & t-value & $P$-value \\
\hline RLI and RL2 & 3 & 2 & 162.15 & $=0.00 I^{*}$ \\
RL2 and RL3 & 3 & 2 & $\mid 144.8 I$ & $<0.00 I^{*}$ \\
RL3 and RL4 & 3 & 2 & -100.45 & $<0.00 I^{*}$ \\
RL4 and RPI & 3 & 2 & -77.33 & $<0.00 I^{*}$ \\
RPI and RP2 & 3 & 2 & 36.792 & $<0.00 I^{*}$ \\
FAI and FA2 & 3 & 2 & 27.166 & $=0.00 I^{*}$ \\
FA2 and FA3 & 3 & 2 & 22.373 & $=0.002^{*}$ \\
MAI and MA4 & 3 & 2 & 14.762 & $=0.005^{*}$ \\
MA4 and MA8 & 3 & 2 & $-4 I .739$ & $<0.00 I^{*}$ \\
MA8 and MAI2 & 3 & 2 & 5.803 & $=0.028^{*}$ \\
MAI2 and MAI4 & 3 & 2 & $-46.2 I 0$ & $<0.00 I^{*}$ \\
MAI4 and MAI8 & 3 & 2 & 38.975 & $<0.00 I^{*}$ \\
QI and Q5 & 3 & 2 & -1893.457 & $<0.00 I^{*}$ \\
Q5 and QI0 & 3 & 2 & -105.15 & $<0.00 I^{*}$ \\
QI0 and QI6 & 3 & 2 & 111.133 & $<0.00 I^{*}$ \\
QI6 and Q2I & 3 & 2 & -89.963 & $<0.00 I^{*}$ \\
Q2I and Q32 & 3 & 2 & 12.028 & $<0.007^{*}$ \\
\hline
\end{tabular}

Note: *Statistical significance $(P<0.05)$.

Abbreviation: SiGBNP, guanine nucleotide binding proteins gene $\beta$-subunit.
Table S2 Paired $t$-test data for comparison of relative SiGNBP gene transcription between LD and HD boric acid treatments in Solenopsis invicta workers

\begin{tabular}{lllll}
\hline Boric acid treatments & N & df & t-value & $P$-value \\
\hline LD and Cont 4d & 3 & 2 & -38.448 & $<0.00 I^{*}$ \\
LD and Cont 8d & 3 & 2 & -32.053 & $<0.00 I^{*}$ \\
LD and Cont I2d & 3 & 2 & -5.023 & $=0.037^{*}$ \\
LD and Cont I4d & 3 & 2 & 104.372 & $<0.00 I^{*}$ \\
HD and Cont 4d & 3 & 2 & 49.802 & $<0.00 I^{*}$ \\
HD and Cont 8d & 3 & 2 & 157.478 & $<0.00 I^{*}$ \\
HD and Cont I2d & 3 & 2 & 73.056 & $<0.00 I^{*}$ \\
HD and Cont I4d & 3 & 2 & 14.788 & $=0.005^{*}$ \\
\hline
\end{tabular}

Note: *Statistical significance $(P<0.05)$.

Abbreviations: SiGNBP, guanine nucleotide binding proteins gene $\beta$-subunit; $L D$, low dose; HD, high dose.
Open Access Insect Physiology

\section{Publish your work in this journal}

Open Access Insect Physiology is an international, peer-reviewed, open access journal publishing original research, reports, reviews and commentaries on all areas of insect physiology. The manuscript management system is completely online and includes a very quick and fair peer-review system, which is all easy to use.

\section{Dovepress}

Visit http://www.dovepress.com/testimonials.php to read real quotes from published authors. 